\title{
Ensifer-mediated transformation: an efficient non-Agrobacterium protocol for the genetic modification of rice
}

\author{
Evelyn Zuniga-Soto ${ }^{1,2^{*}}$, Ewen Mullins ${ }^{2}$ and Beata Dedicova ${ }^{1,3^{*}}$
}

\begin{abstract}
While Agrobacterium-mediated transformation (AMT) remains the most widely used technique for gene transfer in plants, interest exists for the use of non-Agrobacterium gene delivery systems due to freedom-to-operate issues that remain with AMT across several jurisdictions. In addition, the plant pathogenic mode of action of Agrobacterium tumefaciens significantly increases the costs to passage engineered cultivars through the regulatory process. Ensifer adhaerens (OV14) is a soil-related bacterium with the proven ability to genetically modify the model plant $A$. thaliana and the staple crop S. tuberosum (Wendt et al., Trans Res 21:567-578, 2012). While previous work was relevant for dicotyledonous species, in this study, the efficacy of Ensifer adhaerens (OV14)-mediated transformation (EMT) was determined on two japonica rice varieties, Curinga and Nipponbare, and the recalcitrant indica variety, IR64. The results indicated that $E$. adhaerens (OV14) exhibits infection efficiencies ranging between 50-70 \%, 90-100\% and 90-95\% for Curinga, Nipponbare and IR64 respectively. Curinga and Nipponbare plants transformed with E. adhaerens (OV14) and A. tumefaciens (LBA4404 and EHA105) were regenerated achieving transformation efficiencies of $16 \%$ and $26-32 \%$ for Curinga and 7 and $4 \%$ for Nipponbare respectively. Separately, the transformation of IR64 was only recorded via EMT (transformation efficiency 1\%). Integration analyses conducted on 24 transgenic rice lines illustrated that T-DNA insertion occurred randomly throughout the rice genome for EMT (and AMT), with similar integration patterns in the rice genomic DNA observed for both bacterial species.
\end{abstract}

Keywords: Transformation, Rice (Oryza sativa L.), Ensifer adhaerens OV14, T-DNA integration

\section{Background}

Rice (Oryza sativa L.,) remains a stable food for more than half of the world's population but entered the new millennium facing a series of significant challenges relevant to a/biotic stress. Despite the fact that its yields have doubled over the last three decades (FAOSTAT 2013) a constant need exists for new rice cultivars to be developed (Zhang 2007) be that through conventional breeding practises or genetic engineering platforms.

\footnotetext{
*Correspondence: evelin.zuniga@teagasc.ie; beatadedicova@hotmail. com; beata.dedicova@slu.se

2 Department of Crop Science, Teagasc Crops Research Centre, Oak Park, Carlow, Ireland

${ }^{3}$ Present Address: Department of Plant Breeding, Swedish University of Agricultural Sciences (SLU), Box 101, Sundsvägen 10, 23053 Alnarp, Sweden

Full list of author information is available at the end of the article
}

While Agrobacterium mediated transformation (AMT) is widely adopted as the system of choice for engineering novel crop varieties freedom-to-operate issues remain (Chi-Ham et al. 2012), especially in regard to regionalspecific licensing (e.g. in the USA due to US Patent No. 8273954). The cost of securing regulatory approval for AMT-derived lines is also significant primarily due to the plant pathogenic nature of $A$. tumefaciens (CropLife International 2011), which in turn ensures that bringing engineered crop lines through to commercialisation is typically an option exclusive to the largest ag-biotech companies.

Addressing this would require a gene delivery system that is based on a non-pathogenic organism with rates of transformation equivalent to that of AMT for both dicot and monocot species. In 2005 Broothaerts and collaborators demonstrated the efficiency of different Rhizobia

\section{贷 Springer}


species such as Sinorhizobium meliloti, Mesorhizobium loti and NGR 234 (collectively called Transbacter). A more recent approach to the use of non-Agrobacterium species for plant transformation was achieved in 2012 when Wendt et al. (2012), identified the bacterium Ensifer adhaerens strain OV14 as a member of the Rhizobiaceae family with the potential to successfully transform A. thaliana and S. tuberosum.

Similar to A. tumefaciens, E. adhaerens is a gram-negative bacterium belonging to the alphaproteobacteria class; while predatory of prokaryotic cells (Martin 2002) $E$. adhaerens appears to be a plant beneficial bacterium (Zhou et al. 2013). Phylogenetically, this organism is related to non-pathogenic bacteria belonging to the same genera (Garau et al. 2014; Reeve et al. 2014) and the genome sequencing of $E$. adhaerens clearly identified its separation from the Agrobacterium dominated clade of the Rhizobiaceae family (Rudder et al. 2014). In comparing the genome of $E$. adhaerens against $A$. tumefaciens C58 and S. meliloti 1021, the same study concluded that while the E. adhaerens and S. meliloti genomes possessed homologs to chromosomal based genes cited as essential to $A$. tumefaciens T-DNA transfer, it was the E. adhaerens genome that also included genes that while non-essential for transformation do exert a positive influence on virulence and the ability to genetically transform host tissues.

For the regulatory evaluation of engineered varieties, potential risks associated with the product released, including the erroneous presence of vector backbone sequences flanking the T-DNA (FAO 2004) need to be evaluated. It is already known that the expression level of introduced genes can vary substantially between individual transformed plants, probably as a consequence of the influence of different flanking DNA sequences and T-DNA integration patterns (Dietz-Pfeilstetter et al. 2003). For example, based on AMT (dependent on Agrobacterium strain and vectors used), between 20 and $80 \%$ of transgenic plants may contain backbone sequence (Van der Graaff et al. 1996; Kononov et al. 1997; Hanson et al. 1999; De Buck et al. 2000). More specifically, in rice, separate studies have noted the presence of non-T-DNA sequences in $33 \%$ (Yin and Wang 2000), $45 \%$ (Vain et al. 2003), $38 \%$ (Zhai et al. 2004) and indeed in up to $66 \%$ of transgenic lines generated (Afolabi et al. 2004), which serves to complicate any pre-market regulatory assessment should it be required (Wilson et al. 2006). In the present study we describe the protocol development of Ensifer adhaerens (OV14)-mediated transformation for two Japonica rice varieties (Curinga and Nipponbare) and the commercially important indica variety IR64 by using the unitary transformation plasmid pCAMBIA 5105. The protocol applied for Curinga and Nipponbare (Oryza sativa L. spp. japonica) is based on the
CIAT rice protocol developed for various japonica rice species (Tabares et al. 2011); and that for IR64 (Oryza sativa L. spp. indica) is based on Datta and Datta (2006) albeit with several modifications. Furthermore we evaluated the T-DNA integration patterns found in rice plants transformed via E. adhaerens (OV14) and A. tumefaciens (LBA44404 and EHA105 with the pCAMBIA 1305.2 plasmid) in order to evaluate (1) propensity for backbone sequence integration, and (2) insertion patterns (e.g., truncations, filler sequences, and duplications) within the post-integration genome.

\section{Results}

\section{Comparative assessment of Ensifer adhaerens-mediated transformation and Agrobacterium-mediated transformation in rice}

The infection efficiency of E. adhaerens (OV14) was tested in embryogenic Curinga and Nipponbare calli and in immature embryos of IR64 using a histochemical GUS assay (Fig. 1). Comparing the two japonica varieties, it was found that var. Nipponbare was more amenable for infection with $E$. adhaerens (OV14), exhibiting transient GUS activity in more than $90 \%$ of treated calli, meanwhile only $50-70 \%$ of treated Curinga-derived calli reported to be positive for GUS staining following EMT. On the other hand, A. tumefaciens (LBA4404) infection of Nipponbare and Curinga induced GUS staining in between 95 and $100 \%$ and $85-90 \%$ of treated calli, respectively. The infection rate obtained for IR64 with $E$. adhaerens (OV14) was 90-95\%.

From the EMT pipeline the number of transgenic plants regenerated from hygromycin-resistant calli varied among cultivars. For example, from 250 Nipponbare calli, 18 independent Southern blot positive plants were obtained, yielding a transformation efficiency of $7.2 \%$. Fifteen of these turned out to be single copy events, representing $83.3 \%$ of the tested population. For Curinga, 275 calli delivered 45 Southern blot positive plants (transformation efficiency of $16.3 \%$ ), of which $56 \%$ were deemed single copy events (Table 1; Fig. 2).

For A. tumefaciens (LBA4404-pCAMBIA 1305.2); from 400 Curinga infected embryogenic calli (collated from independent experiments) a transformation efficiency of $26.5 \%$ was obtained as per independent integration pattern as per Southern blot. With A. tumefaciens (EHA105pCAMBIA 1305.2), only a single experiment was carried out on Curinga ( $\mathrm{n}=25$ embryogenic calli) and on Nipponbare $(\mathrm{n}=100$ embryogenic calli), which delivered infection efficiencies of 32 and $4 \%$, respectively. For IR64 infected with $E$. adhaerens (OV14), a transformation efficiency of $1 \%$ was recorded from 100 immature embryos but using A. tumefaciens (EHA105-pCAMBIA 1305.2) no transgenic plants were obtained (data not shown). 


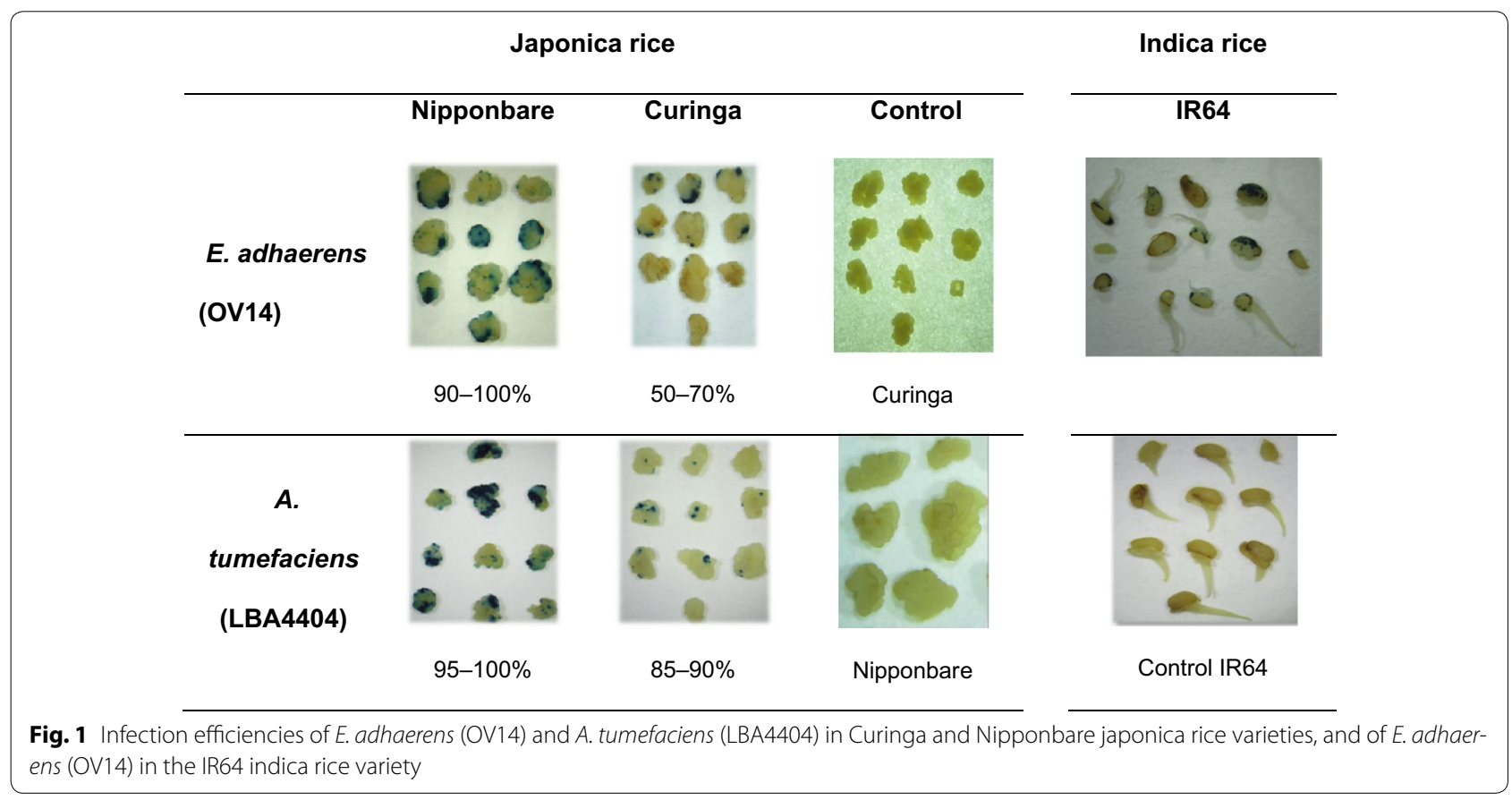

Table 1 Summary table of the transformation events obtained by infecting rice varieties with A. tumefaciens (EHA105 and LBA4404) and E. adhaerens (OV14)

\begin{tabular}{|c|c|c|c|c|c|c|c|c|c|}
\hline $\begin{array}{l}\text { Bacterial } \\
\text { strain }\end{array}$ & $\begin{array}{l}\text { Rice } \\
\text { variety }\end{array}$ & $\begin{array}{l}\text { No. of } \\
\text { infected calli }\end{array}$ & $\begin{array}{l}\text { Plants } \\
\text { delivered }\end{array}$ & PCR (+) & $\begin{array}{l}\text { Southern } \\
\text { blot (+) }\end{array}$ & $1 C$ & $2 C$ & $3 C$ & $\begin{array}{l}\text { Transformation } \\
\text { efficiency (\%) }\end{array}$ \\
\hline E. adhaerens & Nipponbare & 250 & 69 & 20 & 18 & 15 & 1 & 2 & 7.2 \\
\hline E. adhaerens & Curinga & 275 & 73 & 54 & 45 & 25 & 14 & 6 & 16 \\
\hline $\begin{array}{l}\text { A. tumefaciens } \\
\text { (EHA105) }\end{array}$ & Curinga & 25 & 14 & 11 & 8 & 7 & 1 & 0 & 32 \\
\hline $\begin{array}{l}\text { A. tumefaciens } \\
\text { (EHA105) }\end{array}$ & Nipponbare & 100 & 4 & 4 & 4 & 4 & 0 & 0 & 4 \\
\hline $\begin{array}{l}\text { A. tumefaciens } \\
\text { (LBA4404) }\end{array}$ & Curinga & 400 & 133 & 121 & 106 & 56 & 42 & 8 & 26.5 \\
\hline E. adhaerens & IR64 & 100 & 1 & 1 & 1 & 1 & - & - & 1 \\
\hline
\end{tabular}

C stands for "copy number"

Analysis of T-DNA flanking sequences in transgenic plants A chromosome walking approach was employed to characterise the presence/absence of backbone integration at the T-DNA integration sites of EMT and AMT regenerated plants. Twenty four and 13 flanking sequences were obtained for the right and left borders, respectively, from 22 independent single copy transformants of Curinga and Nipponbare using the bacterial strains A. tumefaciens (LBA4404 and EHA105) and E. adhaerens (OV14). The sample 11,197/11,199 corresponds to two "sister" plants originated from the same calli and was used as a control.

Of significance, none of the analysed sequences showed the erroneous integration of adjacent backbone DNA. Evaluating the adjacent sequences from the right border, two different types of configurations were found associated with the T-DNA insertion for both $E$. adhaerens- and A. tumefaciens-transformed plants: (1) partial deletion of the border, (2) complete deletion of the border and adjacent T-DNA.

In agreement with previous reports (Tinland 1996; Stahl et al. 2002; Kumar and Fladung 2002; Zhai et al. 2004) no nucleotides beyond the TGA right-border sequence were found for any line in the present study. Of the 16 japonica plants generated with EMT, four contained the three nucleotides, TGA (line 11,232, 11,422, 1197/99 and 11,473); one, the nucleotides TG (line 11,267); and four only the nucleotide $\mathrm{T}$ (line 11,379, 11,291, 11,414 and 11,471$)$. In three of the sequences analysed, DNA 


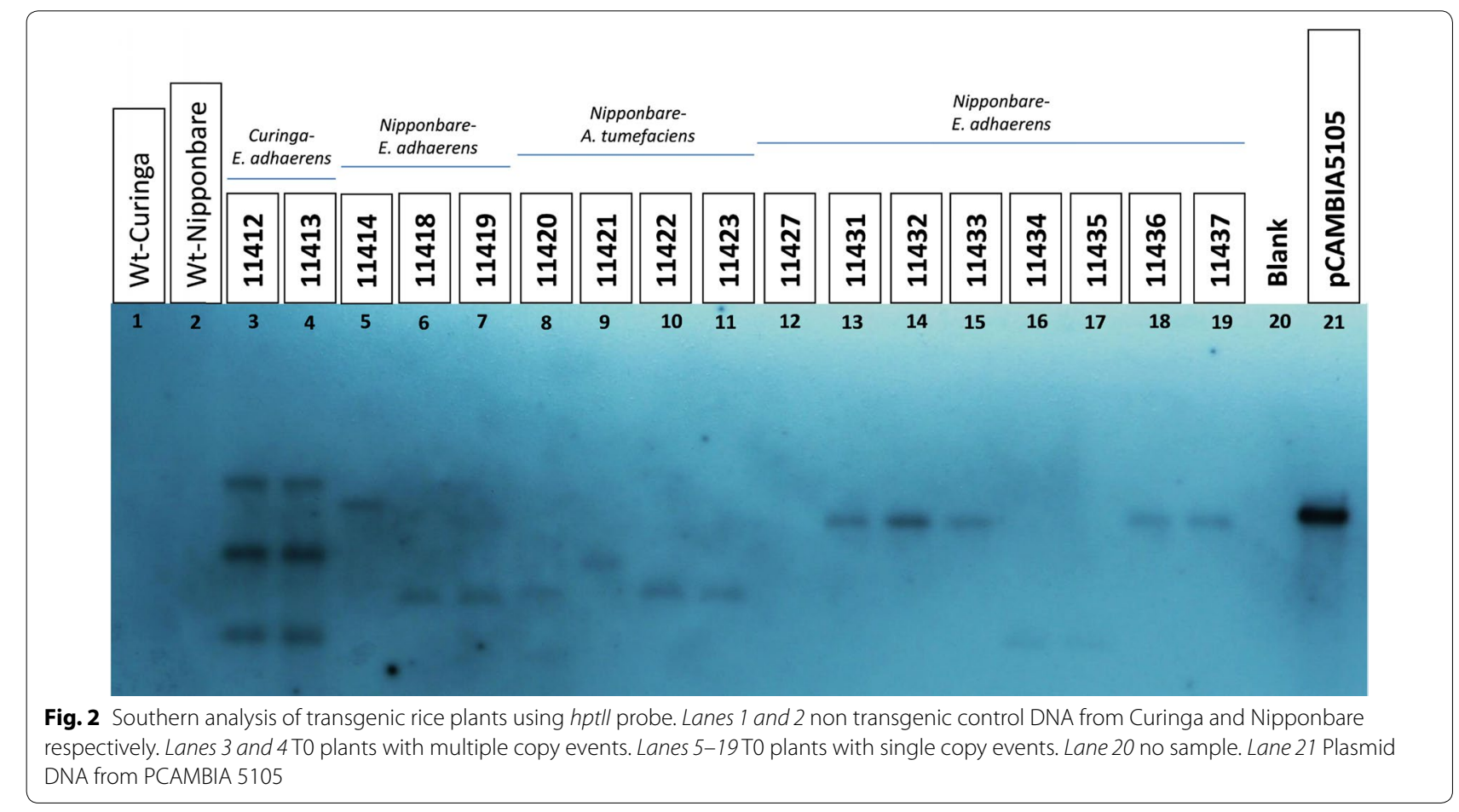

integration led to the loss of $>100-\mathrm{bp}$ of T-DNA (line 11,309, 11,420 and 11,280). Lines with 7-bp (line 11,436 and 11,267), 11-bp (line 11,645) and 25-bp (line 11,253) corresponding to filler sequences were also found. Junctions in which the whole 25-bp of the right border was lost, were found in four lines $(11,814,11,436,11,260$ and $11,813)$. In addition, microhomologies of 4-bp (TGCA) were identified in lines 11,309, 11,420,11,470, 11,418 and 11,267. A 25-bp fragment in the right border (adjacent to the T-DNA) known to correspond as part of the region $3^{\prime}$ UTR polyA signal from the hpt II gene was identified in line 11,253 , this fragment is known to be originally located at the left border of the T-DNA. For the 12 EMT-derived Japonica right-border sequences evaluated, the right border was partially absent from six of them (line 11,197/99, $11,418,11,473,11,276,11,414,11,471$ ), whereas five possessed partial deletions ranging from 17 to 200-bp (line $11,470,11,436,11,253,11,694$ and 11,280). Of the nine AMT-derived japonica sequences assessed, five of them lost the complete length of the right border (line 11,289, $11,309,11,420,11,645$ and 11,814$)$, while the other four had between one and three bases of the right border present (line 11,379, 11,291, 11,232 and 11,422).

Twelve left-border sequences were retrieved for both AMT and EMT regenerated plants. Similarly to the right border, none of the samples showed an integration of erroneous vector backbone sequence. For the left border, characteristics such as truncation of the border and the
T-DNA along with filler sequences were noted. Of the six EMT generated plants that were analysed, four contained remaining left-border portions ranging between 10 to 19-bp (line 11,197/99, 11,260, 11,473 and 11,813) with sample 11,694 also containing a filler segment of 6-bp. One line $(11,471)$ exhibited a truncation of 31 -bp of the T-DNA. Among the five analysed plants obtained with A. tumefaciens (LBA4404 and EHA105), three contained left-border nucleotides ranging between 9 and 17-bp (line $11,291,11,379$ and 11,232), two lines (11,645 and 11,422) contained deletions of 100 and 277-bp respectively, also the line 11,422 included a filler segment corresponding to a 16 -bp fragment of the $h p t$ II gene (Additional file 1: Table S1).

\section{Deleted rice genomic sequences}

T-DNA integration is often accompanied by a small deletion in the plant DNA at the site of insertion (Gheysen et al. 1990). In this study, we analysed a total of 11 transgenic independent lines, all of which showed different degrees of deletion of the rice genome. In the six EMT lines evaluated the deletions ranged between 16 to $273 \mathrm{bp}$ and for the five AMT lines were between 11 to 176 bp (Additional file 1: Table S1).

\section{Integration sites in rice chromosomes}

Mapping the T-DNA flanking sequences on the rice chromosomes revealed no apparent chromosomal position 
preference. T-DNA insertions appeared to be randomly distributed for both $E$. adhaerens and A. tumefaciens (both strains) obtained events. Moreover, the insertions appeared to be evenly distributed along the chromosomes within the rice genome (Fig. 3).

For E. adhaerens (OV14), 10 of the insertions were located in regions outside any predicted genes, four were located in exons, and one in an intron. Similarly, in $A$. tumefaciens (LBA4404 and EHA105) most of the events were located outside any predicted genes with one of them located in an exon and two located in a $3^{\prime}$ UTR region (Table 2).

\section{Discussion}

A. tumefaciens remains the primary bacterial species used for engineering novel crop varieties. Advantageous from the perspective of possessing a wide host range, freedom-to-operate restrictions still remain for the use of AMT be they region specific IP issues and/ or the excessive cost of regulatory approval. Previously, Broothaerts et al. (2005) showed that three non-Agrobacterium species-Rhizobium sp. NGR234, Sinorhizobium meliloti and Mesorhizobium loti-were capable of genetically transforming different plant species. Using $S$. meliloti, Broothaerts et al. infected four of 687 rice calli (cv. Millin) obtaining an infection efficiency of $0.6 \%$. Meanwhile, for the same rice variety, infection with $A$. tumefaciens (EHA105) ranged from 50 to $80 \%$. In 2010, Rahmawati et al. assessed the effectiveness of Rhizobium leguminosarum and S. meliloti transformation compared to that of A. tumefaciens. Infecting Nipponbare (japonica), Rojolele (javanica) and Ciherang (indica) rice varieties, they obtained, GUS transient expression levels of 54, 63 and $46 \%$ respectively with A. tumefaciens

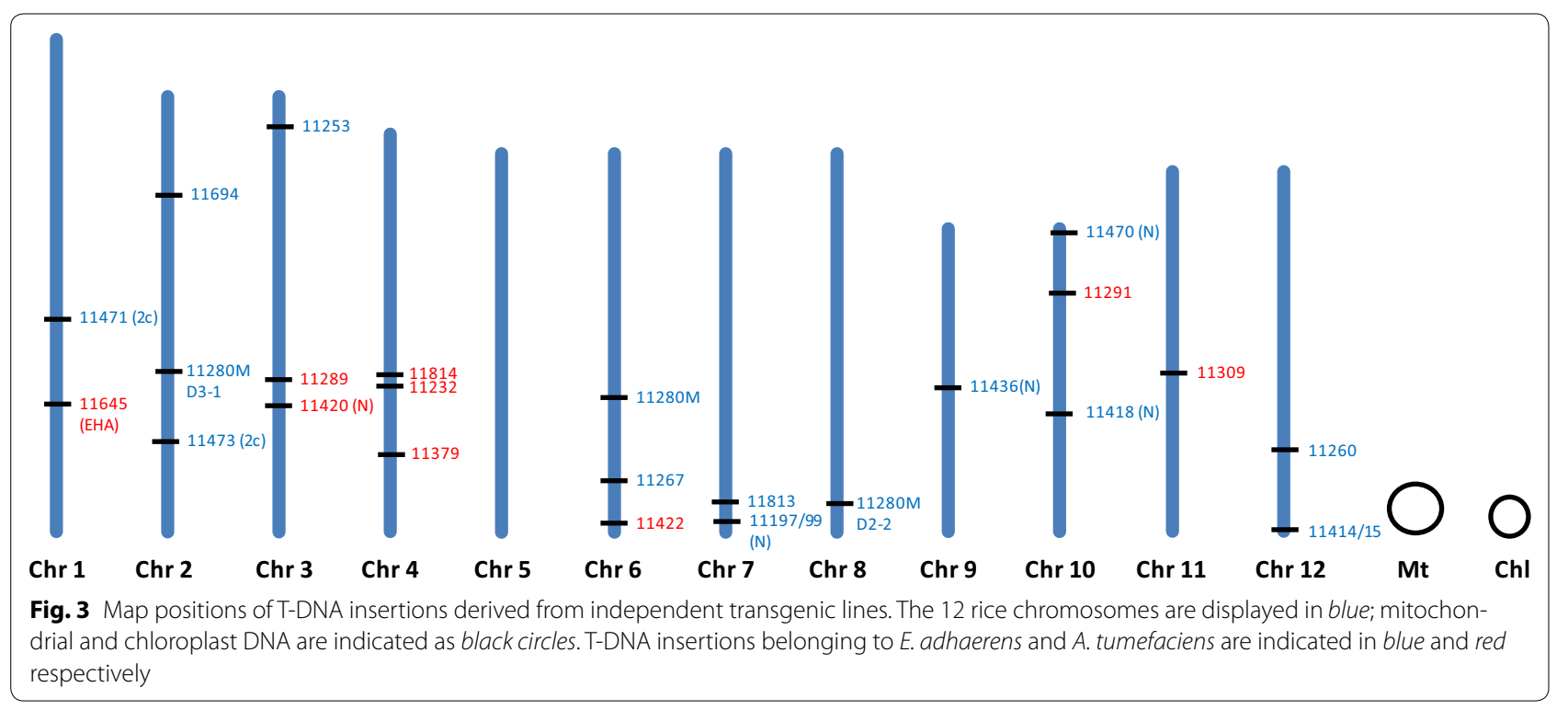

Table 2 Genes and corresponding functions putatively disrupted by T-DNA insertion in via EMT and AMT

\begin{tabular}{llll}
\hline Sample & Gene & Intron/exon & Function \\
\hline EMT & & \\
$11197 / 11199$ & LOC_Os07g48450.1 & Intron & No apical meristem protein, putative, expressed \\
$11280 \mathrm{M} 1$ & LOC_Os06g51490.1 & Exon & PHD-finger domain containing protein, putative, expressed \\
11470 & LOC_Os10g02260.1 & Exon & Peptide transporter PTR2, putative, expressed \\
11471 & LOC_Os01g52380.1 & Exon & Expressed protein \\
11694 & LOC_Os02g13530.1 & Exon & 40S ribosomal protein S24, putative, expressed \\
AMT & & \\
11379 & LOC_Os04g43270.1 & 3' UTR & WAX2, putative, expressed \\
11420 & LOC_Os03g63540.1 & 3'UTR & Lysine-rich arabinogalactan protein 19 precursor, putative, expressed \\
11814 & LOC_Os04g34440.1 & Exon & Ubiquitin interaction motif-containing protein, putative, expressed \\
\hline
\end{tabular}


(LBA288-pCAMBIA 5106); 91, 71 and $68 \%$ with $R$. leguminosarum (ANU845); and 0, 0.91 and $0 \%$ with $S$. meliloti.

Recently Wendt et al. (2012) used E. adhaerens (OV14) for the production of Phytophthora infestans-resistant potato, obtaining an average shoot formation of $35 \%$ in three different experiments. In the present study, we successfully established a reproducible protocol of calli transformation from Nipponbare, Curinga and IR64 rice varieties with the novel non-Agrobacterium species, E. adhaerens (OV14), with an infection efficiency of $90-100 \%, 50-70 \%$ and $80-100 \%$, respectively. These efficiencies are higher than previously reported for other non-Agrobacterium species (Broothaerts et al. 2005) and the corresponding transformation efficiency of $16.3 \%$ for Curinga was in line with the relative efficiency of EMT with respect to AMT as previously reported in dicot crops (Wendt et al. 2012). In regards to Nipponbare, the transformation efficiency of $7.2 \%$ indicates the protocol requires further modification to address escapes and hence obtain higher transformation efficiencies. During this study a single IR64 line was generated from 100 treated immature embryos which were used as the starting material (transformation efficiency: $1 \%$ ). Although low compared to our Japonica rice results, this transformation efficiency is high compared to other nonAgrobacterium species used for indica transformation (Rahmawati et al. 2010), where the rice variety Ciherang achieved $0.23 \%$ of transformation efficiency.

In addition to examining the T-DNA transfer potential of $E$. adhaerens (OV14) in different rice varieties, this study also investigated the T-DNA integration patterns within the transgenic lines obtained. In the analysis of the flanking sequences none of the lines possessed erroneous vector backbone sequence. For the right border, it is important to note that the same integration patterns were obtained for E. adhaerens (OV14) and A. tumefaciens (both strains). When transforming different plant species with $A$. tumefaciens, several studies have reported finding 1-3 bases in the right border sequence: Zhai et al. (2004) using Chinese rice varieties (Minghui63, Yanhui559, Zhenxian97B, Peiai64, C418, Taihujing6, 8706, and Zhonghua11); Kim et al. (2003) in rice cv. Dongjin; Gheysen et al. (1990) using $A$. thaliana; Tinland (1996) with $A$. thaliana and tobacco; Kumar and Fladung (2002) using aspen; and Stahl et al. (2002) using barley. In our results, the junction point in the right border never went beyond these three bases regardless of whether the transformation occurred with A. tumefaciens or E. adhaerens (OV14). This site is a known cleavage site for generating single-stranded T-DNA fragments (Stachel et al. 1987; Yanofsky et al. 1986) and a pattern of integration where the T-DNA is partially deleted in the right or left borders can be explained by a model proposed by Gheysen et al. (1990).

In addition, the well-conserved right T-DNA end supports the hypothesis that the Vir D2 protein attached to the $5^{\prime}$ end accompanies or even guides the T-DNA to the plant nucleus, protecting the right border from degradation (Herrera-Estrella et al. 1988, 1990). Another pattern of insertion found in both borders for A. tumefaciens and $E$. adhaerens generated lines was the finding of filler sequences, which were found adjacent to the T-DNA that do not belong to adjacent rice sequence or vector sequence. In sample 11,470 a filler sequence of $59 \mathrm{bp}$ was found, which, according to the BLAST analysis, is located on rice chromosome 5 . Also we found at the right border of sample 11,253 a 25-bp insertion of a filler sequence from the nucleotides 5468-5495 from the T-DNA in the left border. The last finding can also be explained by one of Gheysen's models denominating Complex Gap Repair. In some instances, the origin of the filler sequences found could not be determined because they were too short (6-8 bp) with homology to several places along the T-DNA and/or adjacent rice genomic DNA.

In addition, deletions of the genomic rice DNA were found in the site of T-DNA insertion in six EMT and 5 AMT lines evaluated. According to different models of T-DNA insertions, deletions occur when illegitimate recombination between the T-DNA and the genomic DNA takes place (Tinland 1996). These deletions have been reported previously in aspen plants (Kumar and Fladung 2002) and in A. thaliana (Forsbach et al. 2003; Mayerhofer et al. 1991); hence, these results suggest that T-DNA integration mechanisms are similar in monocotyledonous and dicotyledonous species and between $E$. adhaerens (OV14) and A. tumefaciens. Although mapping of T-DNA insertions from 22 independent transgenic lines did not reveal a significant bias of T-DNA insertion across the rice genome, there was a tendency for EMT delivered T-DNA to be inserted outside of gene coding regions of the genome, which would assist future regulatory evaluations of those lines engineered through EMT.

This paper confirms the propensity for EMT to genetically transform rice. While the original OV14 strain was isolated from the rhizosphere of a dicotyledonous plant, its utility to transform a monocot is significant. For EMT, the recorded T-DNA integration patterns were typical of illegitimate recombination models and were similar to that observed with AMT derived transgenic lines. Comparing the transformation efficiencies and integration patterns of both bacteria, we concluded that $E$. adhaerens (OV14) is indeed a promising and reliable non-Agrobacterium species with an expanding potential in crop biotechnology. 


\section{Conclusions}

Our results indicate that the non-plant pathogenic $E$. adhaerens (OV14) is able to transform embryogenic rice callus allowing the regeneration of transgenic plants. The integration patterns found in E. adhaerens (OV14) were similar to those found in A. tumefaciens. These analyses lead us to consider that Ensifer-mediated transformation is a reliable alternative to Agrobacterium-mediated transformation for researchers who work on the genetic transformation of rice.

\section{Materials and methods}

\section{Plant material and tissue culture}

Two japonica rice varieties (Oryza sativa L. spp. Curinga and Nipponbare) were selected for transformation with scutellar embryogenic calli used as target tissue. For this purpose, healthy mature dry seeds were manually dehusked, and surface sterilized by being hand shaken in a $50 \%$ Clorox $^{\circledR}$ solution and a drop of Tween 20 for $10 \mathrm{~min}$. Seeds were then rinsed with sterile distilled water 6-7 times before mature embryos (ME) were isolated under a stereoscope onto sterile moistened Whatman ${ }^{\circledR}$ filter paper. For callus induction, $11 \mathrm{ME}$ were placed scutellum side up on calli induction media (CHU-Ind, Table 3) (Chu 1978) and cultured for 20-25 days, after which the formed embryogenic calli were sub-cultured for 8-10 days in fresh CHU-Ind media in darkness at $24-26{ }^{\circ} \mathrm{C}$ to increase the callus size. Proliferated calli were then pre-cultured for 3 days on CHU-Ind-AS media supplemented with $100 \mu \mathrm{M}$ of acetosyringone prior to transformation (in darkness at $24-26{ }^{\circ} \mathrm{C}$ ). For the indica species (IR64) transformation, the seeds were dehusked under stereoscope and were surface sterilized by being hand shaken in $14 \%$ Clorox $^{\circledR}$ solution and a drop of Tween 20 for $10 \mathrm{~min}$. Seeds were rinsed with sterile distilled water 6-7 times. Isolation of immature embryos (IME) was carried out under stereoscope on sterile moistened Whatman ${ }^{\circledR}$ filter paper. For IR64, 15-20 IME were directly isolated in plates supplemented with $300 \mu \mathrm{M}$ of acetosyringone for subsequent transformation.

\section{Bacterial strains used for transformation}

Two A. tumefaciens strains, LBA4404 and EHA105, harbouring the plasmid pCAMBIA 1305.2, and E. adhaerens (OV14), equipped with the unitary plasmid pCAMBIA 5105 were used for rice transformation. pCAMBIA 5105 relies on spectinomycin and npt II (neomycin phosphotransferase) selectable marker genes for bacteria whereas pCAMBIA 1305.2 only relies on $n p t$ II. Both plasmids possess the hpt II (hygromycin phosphotransferase) gene as a plant selectable marker and both carry the GUSPlusHis6 reporter gene.

\section{Transformation}

A primary culture of each bacterial strain A. tumefaciens (LBA4404 and EHA105) and E. adhaerens (OV14) was prepared by inoculating a single colony from a freshly streaked YEP plate in $20 \mathrm{ml}$ of liquid YEP medium. The A. tumefaciens cultures were supplemented with kanamycin $\left(50 \mu \mathrm{g} / \mathrm{ml}^{-1}\right)$ and rifampicin $\left(60 \mu \mathrm{g} / \mathrm{ml}^{-1}\right)$ and the E. adhaerens (OV14) with kanamycin $\left(50 \mu \mathrm{g} / \mathrm{ml}^{-1}\right)$ and spectinomycin $\left(200 \mu \mathrm{g} / \mathrm{ml}^{-1}\right)$. Each culture was incubated overnight in a rotatory shaker at 220-240 rpm in darkness at $28{ }^{\circ} \mathrm{C}$ for $16-18 \mathrm{~h}$. After measuring the optical density of the cultures (A. tumefaciens $=0.5-0.6$, and $E$. adhaerens $=0.3-0.5$ ) the bacteria were centrifuged

Table 3 Media composition for the transformation and regeneration of the japonica rice varieties Curinga and Nipponbare and the indica rice variety IR-64

\begin{tabular}{|c|c|c|}
\hline Medium code & Use & Composition \\
\hline CHU-Ind & Induction and proliferation of calli. & $\begin{array}{l}\text { N6 salts and vitamins (Chu 1978), } 100 \mathrm{mg} \mathrm{I}^{-1} \text { Myo-inositol, } 2.5 \mathrm{mg} \mathrm{l}^{-1} \text { 2,4-D, } 300 \mathrm{mg} \mathrm{I}^{-1} \text { Casein } \\
\text { enzymatic hydrolysate, Maltose } 30 \mathrm{~g} \mathrm{I}^{-1} \text {, Gelrite } 3 \mathrm{~g} \mathrm{I}^{-1} \text {. Autoclave and supplement L-proline } \\
500 \mathrm{mg} \mathrm{I} \mathrm{mg} \mathrm{I}^{-1} \text { and L-glutamine } 500 \mathrm{mg} \mathrm{l}^{-1} \text {. pH } 5.8\end{array}$ \\
\hline CHU-Ind-AS & Co-cultivation & Chu-Ind medium supplemented with $100 \mu \mathrm{M}$ acetosyringone. pH 5.8. \\
\hline CHU-infection & Agro-Infection & $\begin{array}{l}\text { N6 salts and vitamins (Chu 1978), } 100 \mathrm{mg} \mathrm{l}^{-1} \text { Myo-inositol, } 2,5 \mathrm{mg} \mathrm{l}^{-1} \text { 2,4-D, } 1 \mathrm{~g} \mathrm{I}^{-1} \text { Casamino acids, } \\
\text { Maltose } 15 \mathrm{~g} \mathrm{I}^{-1} \text {, Glucose } 15 \mathrm{~g} \mathrm{I}^{-1} . \mathrm{pH}: 5.2 \text {. Filter sterilize. Add sterile acetosyringone } 100 \mu \mathrm{M}\end{array}$ \\
\hline $\begin{array}{l}\mathrm{CHU}-\mathrm{H} 20 \\
\mathrm{CHU}-\mathrm{H} 40 \\
\mathrm{CHU}-\mathrm{H} 30\end{array}$ & Selection & $\begin{array}{l}\text { Chu-Ind medium supplemented with L-proline } 500 \mathrm{mg} \mathrm{l}^{-1} \text {, L-glutamine } 500 \mathrm{mg} \mathrm{l}^{-1} \text {, Gelrite } 3 \mathrm{~g} \mathrm{I}^{-1} \text {, } \\
20 \mathrm{mg} \mathrm{I}^{-1} \text { Hygromycin (for Curinga), } 40 \mathrm{mg} \mathrm{I} \mathrm{I}^{-1} \text { Hygromycin (for Nipponbare), } 30 \mathrm{mg} \mathrm{I}^{-1} \mathrm{Hygro}^{-} \\
\text {mycin (for IR64), } 250 \mathrm{mg} \mathrm{I}^{-1} \text { Cefotaxime. } \mathrm{pH} 5.8\end{array}$ \\
\hline $\begin{array}{l}\text { MS-H20 } \\
\text { MS-H40 } \\
\text { MS-H30 }\end{array}$ & Shoot induction/regeneration & 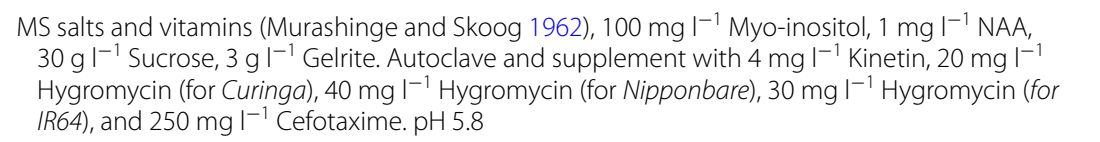 \\
\hline $\begin{array}{l}\text { MS-R-20 } \\
\text { MS-R-40 } \\
\text { MS-R-30 }\end{array}$ & Rooting & 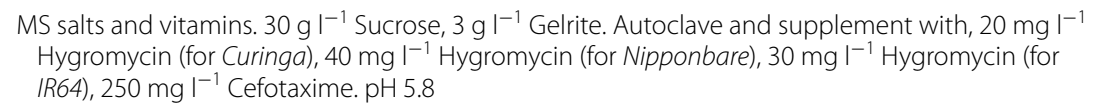 \\
\hline
\end{tabular}


at $4000 \mathrm{rpm}$ for $10 \mathrm{~min}$ and the supernatant discarded. The bacterial pellet was then re-suspended in $20 \mathrm{ml}$ of CHU-infection media supplemented with $100 \mu \mathrm{M}$ of acetosyringone. The resulting culture was then incubated at 200-220 rpm at $21^{\circ} \mathrm{C}$ in darkness. For IR64 transformation using E. adhaerens it was necessary to set the O.D. ${ }_{600}$ to 1.0. The bacterial culture was centrifuged at $4000 \mathrm{rpm}$ for $10 \mathrm{~min}$ and the supernatant discarded. Then the bacterial pellet was re-suspended in $20 \mathrm{ml}$ of $\mathrm{CHU}$-infection media supplemented with $100 \mu \mathrm{M}$ of acetosyringone. The resulting culture was then incubated in darkness at 200-220 rpm and $21^{\circ} \mathrm{C}$ during $1.5-3 \mathrm{~h}$, according to the literature, incubation at low temperature cooperates with the induction of the virulence genes (Baron et al. 2001; Dillen et al. 1997; Hiei et al. 1997).

\section{Tissue infection, selection and regeneration of plants}

For tissue infection, the Curinga rice was infected with A. tumefaciens LBA4404, and the Nipponbare was infected using both $A$. tumefaciens strains, LBA4404 and EHA105. Pre-cultured embryogenic calli of Curinga and Nipponbare (20-30 calli per plate) each received a single drop $(\sim 5 \mu \mathrm{l})$ of the respective bacterial suspension. Cocultivation of the tissue was for 3 days for both bacterial species infecting the japonica rice varieties and 5-7 days for $E$. adhaerens infecting IR64; in both cases the cultures were put in darkness at $21{ }^{\circ} \mathrm{C}$. After co-cultivation, bacterial growth was prevented by washing with autoclaved distilled water plus cefotaxime $\left(500 \mathrm{mg} \mathrm{l}^{-1}\right.$ for the japonica species and $250 \mathrm{mg} \mathrm{l}^{-1}$ for the indica species), and the tissue was dried on sterile filter paper. At this step, tissue (calli and IME) were GUS tested (Jefferson et al. 1989) in order to evaluate the infection efficiency (IE) of both bacterial species with \% IE calculated as the number of calli containing blue spots $\times 100 /$ total number of calli treated.

Following co-cultivation, explants were transferred to selection media amended with hygromycin. For Nipponbare and Curinga, previous assays determined a minimum inhibitory concentration of $40 \mathrm{mg} \mathrm{l}^{-1}$ and $20 \mathrm{mg} \mathrm{l}^{-1}$ of hygromycin, respectively (data not shown). Selection proceeded for $20-30$ days at $24-26{ }^{\circ} \mathrm{C}$ in the dark and after the first round of selection, brown or black calli were removed and only white-creamy embryogenic calli were sub-cultured to fresh $\mathrm{CHU}-\mathrm{H} 20$ medium for a further 15-20 days. After this selection, actively growing pieces of calli were transferred to shoot induction medium (MS-20H for Curinga; MS-40H for Nipponbare) containing hygromycin $\left(20-40 \mathrm{mg} \mathrm{l}^{-1}\right)$ plus cefotaxime $\left(250 \mathrm{mg} \mathrm{l}^{-1}\right)$ for incubation at $24-26{ }^{\circ} \mathrm{C}$ under a $16-\mathrm{h}$ photoperiod until vegetation tissue was visible (in some cases, it was necessary to refresh the media for some calli between days 20 and 30). Following shoot induction, approximately $2-3 \mathrm{~cm}$ plantlets were transferred to rooting media (MS-R for Curinga; MS-R for Nipponbare) supplemented with hygromycin (20-40 $\mathrm{mg} \mathrm{l}^{-1}$ ) and cefotaxime $\left(250 \mathrm{mg} \mathrm{l}^{-1}\right)$. For IR64, plant media set and culture regimes were the same as for the japonica varieties, but selection was performed using hygromycin $30 \mathrm{mg} \mathrm{l}^{-1}$ (Advanced Indica Rice Transformation Training, IRRI, 2012). Transformation efficiency (TE) was calculated as the number of Southern blot positive plants $\times 100 /$ number of infected calli.

\section{Molecular characterization of putative transformants}

For hardening purposes, plantlets $7-10 \mathrm{~cm}$ long were transferred to falcon tubes or glass jars and covered with a small translucent bag to maintain humidity for $3-4$ days at $24-26{ }^{\circ} \mathrm{C}$ with a $16-\mathrm{h}$ photoperiod, after which plantlets were transferred to a hydroponic solution protocol (Subbarao et al. 2007). Within 10 days, a 5-7 cm long (100-150 mg) section of leaf tissue was excised for DNA extraction using an Alkyltrimethylammonium bromide (MATAB) modified method (Murray and Thompson 1980) and chloroform:isoamylalcohol (24:1). PCR analysis was used to confirm the presence or absence of the transgene in primary transformants $\left(\mathrm{T}_{0}\right)$ with the constitutive gene OsNAC and the selection gene hpt II employed to assess DNA quality and transgene identification, respectively. The primer sequences were: OsNAC6-Rv 5'-GTTACTCG TGCATGATCCAC-3', OsNAC6/n $5^{\prime}$-ATGAGCGGCGGTCAGGACCTGCA-3' (Acc. No EU84 6993.1), HPT-RKFw5'C TATTCCTTTGCCTTCGGACG-3' and HPT-RKRv 5'-CTCCGCATTGGTCTTGACCA- $3^{\prime}$. In both genes, the $20 \mu \mathrm{l}$ reaction mixture contained $1 \mathrm{X}$ GoTaq $^{\circledR}$ Green Master mix (Promega Cat. No. M7123), $0.25 \mu \mathrm{M}$ of each primer and $\sim 50 \mathrm{ng}$ of template. Cycling conditions were $95{ }^{\circ} \mathrm{C}$ (2 min), followed by 35 cycles of denaturation at $94{ }^{\circ} \mathrm{C}$ (30 s), annealing at $55{ }^{\circ} \mathrm{C}(30 \mathrm{~s})$ and extension at $72{ }^{\circ} \mathrm{C}$ (1 min), with a final extension of $72{ }^{\circ} \mathrm{C}(5 \mathrm{~min})$. Five $\mu \mathrm{l}$ of the PCR product were resolved in a SYBR-Safe $1 \%$ stained gel. To verify the copy number of the transgenic plants, Southern blot was performed by digesting $10 \mu \mathrm{g}$ of DNA using $50 \mathrm{U}$ of the enzyme EcoRI (Life technologies ${ }^{\circledR}$ ) Additional file 2: Figure S1. Digested DNA was resolved in a $1 \%$ agarose gel and transferred on a nitrocellulose membrane (GE Healthcare) before probing a $228 \mathrm{bp}$ fragment of the $h p t$ II gene chemically labelled with Dig-dUTP $\left(\right.$ ROCHE $\left.^{\circledR}\right)$. Hybridization was performed at $42{ }^{\circ} \mathrm{C}$ overnight and the membrane washing was completed according to the manufacturer's instructions. Transgene integration analysis was conducted on single copy lines as confirmed via Southern blotting. An adapter ligation PCR approach from Hagiwara and Harris (1996) was used to extract the flanking chromosomal rice sequences from the T-DNA in the left border of both 
plasmids, pCAMBIA 5105 and pCAMBIA 1305.2. DNA was digested using the blunt-end cutters, AfeI, MscI and SfoI.

At the same time, the following oligonucleotides, V-top 5'-GAAGGAGAGGACGCTGTCTGT CGAAGGTAAGGAACGGACGAGAGAAGGGAGAG-3' and V-bottom 5'CTCTCCCTTCT C GAATCGTAACCGTTCGTACGAGAATCGCTGTCCTCTCCTTC-3', were synthesized, purified and dissolved in distilled water to a final concentration of $4 \mu \mathrm{M}$ each to form the "vectorette unit", which was linked to the digested DNA. $\mathrm{V}$-top and V-bottom sequences are complementary to each other except in the middle part, where the primer, 224M13 (5'-TGTAAAACGACGGCCAGTCGAATCGTAACCGTTCGTACGAGAATCGCT- $3^{\prime}$ ), attaches to the bubble-like structure formed allowing the amplification of the unknown DNA rice region and respective adjacent vector sequence. The sequences obtained for the right border were analysed using the BLAST tool from the Rice Genome database (http://rice.plantbiology.msu. edu/-Os-Nipponbare-Reference-IRGSP-1.0 Pseudomolecules) to obtain the position, flanking sequences and T-DNA integration pattern of the sequences. Using the data retrieved from BLAST, we designed primers within the rice genomic sequence adjacent to the T-DNA insertion in the left border to amplify and isolate the flanking sequence.

\section{Growth conditions for $\mathrm{T}_{0}$ plants and $\mathrm{T}_{1}$ seed production}

PCR-positive $T_{0}$ plants from the three varieties were moved into hydroponic cultures in the greenhouse and grown according to Subbarao et al. (2007) for 2 weeks. Once Southern blot analyses were completed, $\mathrm{T}_{0}$ plants with single inserts and well-established root systems were subsequently transplanted into clay soil for further growth. Self-pollinated progenies $\left(T_{1}\right.$ seeds) were harvested within a 3 -month period. The $\mathrm{T}_{1}$ seeds were manually harvested, cleaned and stored at $4{ }^{\circ} \mathrm{C}$.

\section{Additional files}

Additional file 1: Table S1. Rice DNA/T-DNA border sequences. T-DNA REF: corresponds to the native T-DNA sequence plus the complete right border. blue: fragments of the right border sequences; orange: fragments of the left border sequences; green: adjacent rice genomic DNA sequence; red: filler sequences; underlined: microhomologies; capital black letter: T-DNA fragment.

Additional file 2: Figure S1. Schematic representation of the plasmid pCAMBIA 5105 indicating EcoRI restriction site and luciferase probe used for Southern blot analysis.

\section{Authors' contributions}

EZS performed all transformation experiments and molecular work, collected data and interpreted the results and drafted the manuscript. EM provided Ensifer adhaerens (OV14) bacterial strain for this work and assisted in drafting the manuscript. BD supervised the rice project and assisted in drafting the manuscript. All authors read and approved the final manuscript.

\section{Author details}

${ }^{1}$ International Center for Tropical Agriculture (CIAT) Transformation Platform, International Center for Tropical Agriculture (CIAT), A.A. 6713 Cali, Colombia. 2 Department of Crop Science, Teagasc Crops Research Centre, Oak Park, Carlow, Ireland. ${ }^{3}$ Present Address: Department of Plant Breeding, Swedish University of Agricultural Sciences (SLU), Box 101, Sundsvägen 10, 23053 Alnarp, Sweden.

\section{Acknowledgements}

The authors wish to acknowledge Mr. D. Marin and Mr. G. Delgado for providing the embryogenic tissue for the transformation experiments and for taking care of the T0 plants in the Biosafety greenhouse. This research work was supported by the Global Rice Science Partnership (GRiSP) Initiative, through the New Frontier Research Project during 2012-2014.

\section{Competing interests}

E. Mullins is an author of patent application PCT/EP2010/070681 which details the use of an isolated Ensifer adhaerens strain OV14 deposited under NCIMB Accession Number 41777 as a gene delivery system in the genetic transformation of plant material. Our manuscript has in no way been affected by this fact, nor has our participation in the work influenced in any manner the analysis of the generated datasets and/or the conclusions drawn.

Received: 28 January 2015 Accepted: 24 September 2015

Published online: 13 October 2015

\section{References}

Advanced Indica Rice Transformation Training (2012) International Rice Research Institute (IRRI), Manila

Afolabi AS, Worland B, Snape J, Vain P (2004) A large-scale study of rice plants transformed with different T-DNAs provides new insights into locus composition and T-DNA linkage configurations. Theor Appl Genet 109:815-826

Baron C, Domke N, Beinhofer M, Hapfelmeier S (2001) Elevated temperature differentially affects virulence, VirB protein accumulation, and T-pilus formation in different Agrobacterium tumefaciens and Agrobacterium vitis strains. J Bacteriol 183:6852-6861. doi:10.1128/ JB.183.23.6852-6861.2001

Broothaerts W, Mitchell HJ, Wier B et al (2005) Gene transfer to plants by diverse species of bacteria. Nature 433:629-633

Chi-Ham CL, Boettiger S, Figueroa-Balderas R, Bird S, Geoola JN, Zamora P, Alandete-Saez M, Bennett AB (2012) An intellectual property sharing initiative in agricultural biotechnology: development of broadly accessible technologies for plant transformation. Plant Biotechnol J 10:501-510

Chu CC (1978) The N6 medium and its application to anther cultures of cereal crops. Proc Symp Plant Tissue Cult. doi:10.1079/IVP2003501

CropLife International (2011) Getting a biotech crop to market. http://croplife org/plant-biotechnology/regulatory-2/costof-bringing-a-biotech-cropto-market/. Accessed 16 July 2015

Datta K, Datta SK (2006) Indica rice (Oryza sativa, BR29 and IR-64). In: Wang K (ed) Methods in molecular biology. Agrobacterium protocols. Humana Press, New York, pp 201-211

De Buck S, Wilde CD, Van Montague M, Depicker A (2000) T-DNA vector backbone sequences are frequently integrated into the genome of transgenic plants obtained by Agrobacterium-mediated transformation. Mol Breed 6:459-468. doi:10.1023/A:1026575524345

Dietz-Pfeilstetter A, Arndt N, Kay V, Bode J (2003) Molecular structure and regulatory potential of a T-DNA integration site in petunia. Transgenic Res 12:83-99

Dillen W, De Clercq J, Kapila J, Zambre M, Van Montagu M, Angenon $\mathrm{G}$ (1997) The effect of temperature on Agrobacterium tumefaciens-mediated gene transfer to plants. Plant J 12:1459-1463. doi:10.1046/j.1365-313x.1997.12061459.x

FAO (2004) The state of food and agriculture. FAO Agriculture series No. 35 FAO (2013) FAOSTAT. http://faostat.fao.org 
Forsbach A, Schubert D, Lechtenberg B et al (2003) A comprehensive characterization of single-copy T-DNA insertions in the Arabidopsis thaliana genome. Plant Mol Biol 52:161-176

Gheysen G, Villarroel R, Montagu M (1990) Illegitimate recombination in plants: a model for T-DNA integration. Genes Dev 5:287-297. doi:10.1101/ gad.5.2.287

Hagiwara K, Harris CC (1996) 'Long distance sequencer' method: a novel strategy for large DNA sequencing projects. Nucleic Acids Res 24:2460-2461

Herrera-Estrella A, Chen ZM, Van Montagu M, Wang K (1988) VirD proteins of Agrobacterium tumefaciens are required for the formation of a covalent DNA-protein complex at the 5 'terminus of T-strand molecules. EMBO J 7:4055-4562

Herrera-Estrella A, Van Montagu M, Wang K (1990) A bacterial peptide acting as a plant nuclear targeting signal: the amino-terminal portion of Agrobacterium VirD2 protein directs a beta-galactosidase fusion protein into tobacco nuclei. Proc Natl Acad Sci USA 87:9534-9537

Hiei Y, Komari T, Kubo T (1997) Transformation of rice mediated by Agrobacterium tumefaciens. Plant Mol Biol 35:205-218

Jefferson RA, Karanagh TA, Bevan MW (1989) GUS fusions: $\beta$-glucuronidase as a sensitive and versatile gene fusion marker in higher plants. EMBO J 6:3901-3907

Kim S, Jinwon L, Jun S-H et al (2003) Transgene structures in T-DNA-inserted rice plants. Plant Mol Biol 52:761-773

Kononov ME, Bassuner B, Gelvin SB (1997) Integration of T-DNA binary vector 'backbone' sequences into the tobacco genome: evidence for multiple complex patterns of integration. Plant J 11:945-957

Kumar S, Fladung M (2002) Transgene integration in aspen: structure of integration sites and mechanism of T-DNA integration. Plant J 31:543-551

Martin M (2002) Predatory prokaryotes: an emerging research opportunity. J Mol Microbiol Biotechnol 4:467-477

Mayerhofer R, Koncz-Kalman Z, Nawrath C (1991) T-DNA integration: a mode of illegitimate recombination in plants. EMBO J 10:697-704

Murashige T, Skoog F (1962) A revised medium for rapid growth and bioassays with tobacco tissue cultures. Physiol Plantarum 15:473-479

Murray M, Thompson W (1980) Rapid isolation of high molecular weight plant DNA. Nucleic Acids Res 10:4321-4325

Rahmawati S, Jefferson O, Sopandie D, Slamet-Loedin I (2010) Comparative analysis of rice transformation using Agrobacterium tumefaciens and Rhyzobium leguminosarum. Indones J Biotechnol 15:37-45

Reeve W, Tian R, Bräu L, Goodwin L, Munk C, Detter C, Tapia R, Han C, Liolios K, Huntemann M, Pati A, Woyke T, Mavrommatis K, Markowitz V, Ivanova N, Kyrpides N, Willems A (2014) Genome sequence of Ensifer arboris strain LMG 14919T; a microsymbiont of the legume Prosopis chilensis growing in Kosti, Sudan. Stand Genom Sci 9:473-483. doi:10.4056/sigs.4828625

Rudder S, Doohan F, Creevey CJ, Wendt T, Mullins E (2014) Genome sequence of Ensifer adhaerens OV14 provides insights into its ability as a novel vector for the genetic transformation of plant genomes. BMC Genom 15:268. doi:10.1186/1471-2164-15-268
Stachel SE, Timmerman B, Zambryski P (1987) Activation of Agrobacterium tumefaciens vir gene expression generates multiple single-stranded T-strand molecules from the pTiA6 T-region: requirement for 5 virD gene products. EMBO J 6:857-863

Stahl R, Horvath H, Van Fleet J et al (2002) T-DNA integration into the barley genome from single and double cassette vectors. Proc Natl Acad Sci USA 99:2146-2151. doi:10.1073/pnas.032645299

Subbarao GV, Wang HY, Ito O, Nakahara K, Berry WL (2007) NH4+ triggers the synthesis and release of biological nitrification inhibition compounds in Brachiaria humidicola roots. Plant Soil 290:245-257. doi:10.1007/ s11104-006-9156-6

Tabares E, Umenura Y, Rane J, Ishitani M, Dedicova B, Tohme J (2011) CIAT transformation platform and rice pipeline. In: Plant Transformation Technologies II. Book of Abstracts 19-22 February, Vienna, Austria, p 60

Tinland B (1996) The integration of T-DNA into plant genomes. Trends Plant Sci 1:178-184. doi:10.1016/1360-1385(96)10020-0

Vain P, Afolabi A, Worland B, Snape JW (2003) Transgene behaviour in populations of rice plants transformed using a new dual binary vector system: pGreen/pSoup. Theor Appl Genet 107:210-217

Van der Graaff E, den Dulk-Ras A, Hooykaas PJJ (1996) Deviating T-DNA transfer from Agrobacterium tumefaciens to plants. Plant Mol Biol 31:677-681

Wendt T, Doohan F, Mullins E (2012) Production of Phytophtora infestance resistance potato (Solanum tuberosum) utilizing Ensifer adhearence OV 14. Trans Res 21:567-578

Wilson AK, Latham J, Steinbrecher RA (2006) Transformation-induced mutations in transgenic plants: analysis and biosafety implications. Biotechnol Genet Eng Rev 23:209-238. doi:10.1080/02648725.2006.10648085

Yanofsky MF, Porter SG, Young C et al (1986) The virD operon of Agrobacterium tumefaciens encodes a site-specific endonuclease. Cell 47:471-477

Yin Z, Wang GL (2000) Evidence of multiple complex patterns of T-DNA integration into the rice genome. Theor Appl Genet 100:461-470

Zhai W, Chen C, Zhu X, Chen X, Zhang D, Li X, Zhu L (2004) Analysis of T-DNAXa21 loci and bacterial blight resistance effects of the transgene Xa21 in transgenic rice. Theor Appl Genet 109:534-542

Zhang Q (2007) Strategies for developing Green Super Rice. Proc Natl Acad Sci USA 10:16402-16409. doi:10.1073/pnas.0708013104

Zhou G, Wang Y, Zhai S, Ge F, Liu Z, Dai Y, Yuan S, Hou J (2013) Biodegradation of the neonicotinoid insecticide thiamethoxam by the nitrogenfixing and plant-growth-promoting rhizobacterium Ensifer adhaerens strain TMX-23. Appl Microbiol Biotechnol 97:4065-4074. doi:10.1007/ s00253-012-4638-3

\section{Submit your manuscript to a SpringerOpen ${ }^{\odot}$ journal and benefit from:}

- Convenient online submission

- Rigorous peer review

- Immediate publication on acceptance

- Open access: articles freely available online

- High visibility within the field

- Retaining the copyright to your article

Submit your next manuscript at $>$ springeropen.com 